\title{
The effects of anacardium occidentale leave extract on histology of selected organs of Wistar rats
}

\begin{abstract}
Medicinal plants are believed to be an important source of new chemical substances with potential therapeutic effects. The cashew (Anacardium occidentale) is a tree in the family of the flowering plant Anacardiaceae. The family contains 73 genera and about 600 species. Anacardium contains 8 species, native to tropical America, of which the cashew is by far the most important economically. It is a multipurpose tree of the Amazon that grows up to $15 \mathrm{~m}$ high. It has a thick and tortuous trunk with branches so winding that they frequently reach the ground. The cashew tree produces many resources and products. The bark and leaves are used medicinally. The cashew nut has international appeal and market value as food. Even the shell oil around the nut is used medicinally and has industrial applications in plastics and resin industries for its phenol content. The pseudo-fruit, a large pulpy and juicy part, have a fine sweet flavor and is commonly referred to as the 'cashew fruit' or the cashew apple. Cashew leaf and bark tea is used in Brazil and Peruvian herbal medicine, Tikinia in northwest Amazona, Wayapi tribe of Guyana as a douche for vaginal discharge and common diarrhea remedy. In Brazil, it is also used to treat diabetes, weakness, muscular debility, urinary disorders, asthma, eczema, psoriasis, scrofula, dyspepsia, genital problems, bronchitis, cough, intestinal colic, leishmaniasis, venereal disease, as well as impotence, and syphilis-related skin disorders. The general objective of this study is to evaluate the general effect of this plant (A. occidentale) extract on the histological architecture of selected organs of wistar rats. Empirical and Physical Measurements of wistar rats treated with oral administration of $A$. occidentale leaf extract for 28 days. The results obtained in this study revealed that the ethanolic extract of Anacardium occidentale at low and high doses $(200$, and $600 \mathrm{mg} / \mathrm{kg}$ body weight in wistar rats) adversely affect the liver. In addition, the hepatocyte (kupffer cells) of the liver of the wistar rats that received a low $(200 \mathrm{mg} /$ $\mathrm{kg}$ body weight) and high dose $(600 \mathrm{mg} / \mathrm{kg}$ body weight) of the ethanolic extract showed more activation of the kupffer cells to the toxic extract. Therefore, it is impossible that the functions of the liver as a major metabolic and immunologic organ may be adversely affected
\end{abstract}

Keywords: liver, anacardium occidentale, histological
Volume 2 Issue 2 - 2017

\author{
Godfrey Innocent lyare, 1,3 Nosa Terry \\ Omorodion, ${ }^{2}$ Theophilus Ogie Erameh,' \\ Peter Uwadiegwu Achukwu, ${ }^{3}$ Anaziah Grace \\ Ogochukwu' \\ 'Department of Medical Laboratory Science, Igbinedion \\ University, Nigeria \\ ${ }^{2}$ Health Services Department, University of Benin, Nigeria \\ ${ }^{3}$ Department of Medical Laboratory Science, University of \\ Nigeria, Nigeria
}

Correspondence: Nosa Terry Omorodion, Health Services Department, University of Benin, Nigeria, Tel 08|36742270, Email terry.omorodion@uniben.edu

Received: September 13, 2017 | Published: November 10, 2017

\section{Introduction}

Medicinal plants are believed to be an important source of new chemical substances with potential therapeutic effects. ${ }^{1}$ The cashew (A. occidentale) is a tree in the family of the flowering plant Anacardiaceae. The family contains 73 genera and about 600 species. Anacardium contains 8 species, native to tropical America, of which the cashew is by far the most important economically. It is a multipurpose tree of the amazon that grows up to $15 \mathrm{~m}$ high. It has a thick and tortuous trunk with branches so winding that they frequently reach the ground The cashew tree produces many resources and products. The bark and leaves are used medicinally. The cashew nut has international appeal and market value as food. Even the shell oil around the nut is used medicinally and has industrial applications in plastics and resin industries for its phenol content. The pseudo-fruit, a large pulpy and juicy part, have a fine sweet flavor and is commonly referred to as the "cashew fruit' or the "cashew apple". Cashew leaf and bark tea is used in Brazil and Peruvian herbal medicine, Tikinia in northwest Amazona, Wayapi tribe of Guyana as a douche for vaginal discharge and common diarrhea remedy. In Brazil, it is also used to treat diabetes, weakness, muscular debility, urinary disorders, asthma, eczema, psoriasis, scrofula, dyspepsia, genital problems, bronchitis, cough, intestinal colic, leishmaniasis, venereal disease, as well as impotence, and syphilis-related skin disorders. ${ }^{2}$ In the sixteenth- century, Brazil cashew fruits and their juice were taken by Europeans to treat fever, sweeten breath, and "conserve the stomach". It is taken for syphilis and as a diuretic, stimulant and aphrodisiac. In addition to being delicious, cashew fruit is a rich source of vitamins, minerals and other essential nutrients. It has up to five times vitamin $\mathrm{C}$ than oranges and contains a high amount of mineral salts. Because of its high amount of amount of vitamin $\mathrm{C}$ and mineral salts, cashew fruit is used as a catalyst in the treatment of premature ageing of the skin. Several clinical studies have shown that anacardiac acid is a component of cashew, with highest concentration in the nutshells curb the darkening effect of ageing by inhibiting tyrosinase activity, and that they are toxic to certain cancer cells ${ }^{3,4}$ reveal a unique function of anacardic acid in that, for dietary conditions enhancing body fat deposition that is consumption of a diet high in carbohydrates, dietary anacardic acid has the potential to decrease body fat deposition. In the last 20 years, the interest in medicinal plants has increased together with the number of investigations into their biological effects on human beings and animals. ${ }^{5}$ Although, poisonous plants are ubiquitous, herbal medicine is used by up to $80 \%$ of the population in the developing countries.

Cashew gum is used in pharmaceuticals and as substitute for gum Arabic. Extracts from roots, stems and fruits of $A$. occidentale leaf have been used by the Cameroonian and other countries' folk medicine. In the traditional Nigerian and Brazilian pharmacopoeia, stem bark of 
A. occidentale Leaf is known for its anti-inflammatory effects ${ }^{7}$ The leaves and/or the bark is also used in Brazil for eczema, Psoriasis, Scrofula, Dyspepsia, genital problems, and venereal diseases, as well as for impotence, bronchitis, cough, intestinal colic, leishmaniasis and syphilis-related skin disorders. ${ }^{8}$ A strong antioxidant capacity was also observed against hepatocarcinogenesis induced by aflatoxin B1 in Winstar rat. ${ }^{8}$ Preclinical studies reveals that metabolites isolated from the bark of cashew tree demonstrated antipyretic action for anacardic acid ${ }^{9}$ realized mutagenic tests with vegetable oil derived from cashew nut, which presented mutagenicity with or without the activation of the S9 fraction in Salmonella thyphimurium. H..$^{10,11}$ demonstrated that tannic acid, a compound present in the cashew, presented an antimutagenic effect on the Salmonella thyphimurium TA98 lineage. The bark and leaves of cashew are a rich source of tannins, a group of plant chemicals with documented biological activity. ${ }^{12}$ These tannins, in a 2004 rat study, demonstrated anti-inflammatory and astringent effects, which may be why cashew is effective in treating diarrhea. ${ }^{12}$ Several clinical studies have shown that tannins has therapeutic property of curbing the darkening effect of aging by inhibiting tyrosinase activity, and that they also serve as therapeutic effect to certain cancer cells. ${ }^{3}$ Reported that $A$. occidentale do not have a toxic effect on the brain and kidney of Swiss albino rat. ${ }^{13}$ Reported that small quantity of cashew extract less than $6 \mathrm{~g} / \mathrm{kg}$ has no toxic effect on rats and high doses may have side effects. The aim of this study is to determine the effect of $A$. occidentale leave extract on histology of selected organs of wistar rats. The general objective of this study is to evaluate the general effect of this plant (A. occidentale) extract on the histological architecture of selected organs of wistar rat.

\section{Materials and methods}

This study was conducted at the Department of Medical Laboratory Science, School of Basic Medical Sciences, College of Medical Sciences, Igbinedion University Okada, Edo State, BeninCity, Nigeria. Animal acclimatization, extract preparation and administration, Grossing, Tissue Processing, Sectioning, Staining, Microscopy and Photomicrography lasted for three months (MayJuly 2017). Standard Histological methods and materials were used, while modifications were made where necessary. ${ }^{14}$ The animal study was carried out in compliance with the policies outlined in the 'Guide for the Care and Use of Laboratory Animals, published by the US National Institute of Health (NIH Publication No.85-23, revised 1996). The rats were obtained from the Animal house of the Department of Biochemistry, Faculty of Life Science, Igbinedion University Okada, Edo state, Benin City, Nigeria. Twenty (20) in-bred white rats of both sexes (Rattus norvergicus) of about 2-4months old and an average body weight of 130.3-213.9g, were selected into five (5) groups of 4 rats per cage and labelled as cages A,B,C,D and E. The animals were housed in wire gauze cage with saw dust as beddings to acclimatize, in the animal house of the Department of Biochemistry, Igbinedion University Okada, for 2 weeks, under standard condition of temperature $\left(25 \pm 5^{\circ} \mathrm{C}\right)$ and a light/dark periodicity of 12:12hours. Enough food (Standard Top feed ${ }^{\circledR}$ ) and water was provided ad libitum. Behavioral signs of acute toxicity were observed in experimental animals and were noted; such as: diarrhea, watery stool, hair loss, stretching, reduced activities, dullness, restlessness, paw licking and salivation. The leaves of $A$. occidentale was plucked from $A$. occidentale tree, behind final year block, opposite New Private Hostel, New Girls Hostel, Crown Estate, Igbinedion University Okada. The leaves were identified and authenticated at Botany department, Igbinedion University Teaching Hospital, Okada, Edo State, Benin City. After proper identification of the plant, it washed thoroughly washed with tap water and allowed to air dry under the sun for some days. The dried leaves was pulverized into uniform powder using a household blender and sieved to obtain a fine powdered particle. Thereafter, 700 grams of the pulverized sieved, fine powdered particle was measured using a weighing balance. Seven liters (7L) of commercially purchased ethanol was measured and added with a measuring cylinder. Heat was applied for 10 minutes at $100^{\circ} \mathrm{C}$ in a hot air oven. The heated, boiled mixture was transferred to the GFL Shaker (No $3017 \mathrm{MBH}$, Germany) while the mixture was mechanically agitated for 8hours. It was left on the bench for 12 hours before filtration under suction pressure with a Whatman's filter paper. Filtrate was concentrated under reduced pressure in a rotary evaporator (Buchi, Switzerland), lyophilized (Christ Alpha 1-2LD, Germany) and stored at $4^{\circ} \mathrm{C}$ for experimental use. The process was repeated to obtain a total extract yield of about $500 \mathrm{gm}$ for experimental use. The median lethal dose $\left(\mathrm{LD}_{50}\right)$ of $A$. occidentale leaf aqueous extract was determined in the rat using Lorke's Method (1983) presented in ${ }^{15}$ and was further modified in the present study.

\section{This study was conducted in $\mathbf{2}$ phases}

Phase 1: In the first phase, sixteen rats were grouped into four groups $(1,2,3$, and 4$)$ with four rats in each cage. Phase 1 had the following concentration to the rats $200 \mathrm{mg} / \mathrm{kg}, 400 \mathrm{mg} / \mathrm{kg}, 800 \mathrm{mg} / \mathrm{kg}, 1600 \mathrm{mg} /$ $\mathrm{kg}$ of test substrates. The animals were placed under observation for signs of toxicity which includes but were not limited to paw licking, salivation, stretching, weakness, reduced activities, dullness, sleep, respiratory distress, coma and death in the first (4hrs) and subsequently daily for 7days.

Phase 2: This phase was grouped into $(5,6,7$, and 8$)$ with four rats in each cage/group. Phase 2 had the following concentration $3200 \mathrm{mg} /$ $\mathrm{kg}, 12800 \mathrm{mg} / \mathrm{kg}, 25600 \mathrm{mg} / \mathrm{kg}, 51200 \mathrm{mg} / \mathrm{kg}$ of the test substrate. The animals were placed under observation for signs of toxicity and mortality for the first critical four (4hrs) and thereafter daily for 7 days. The both phases were separately administered orally to the mice in each of the test groups. Each of the mice in the control group was treated only with distilled water $(300 \mathrm{mg} / \mathrm{kg})$. The mice in both the test and control group were then allowed free access to food and water and observed over a period of hours for signs of acute toxicity. The number of deaths (caused by the extract) with the period of time was noted and recorded. Log dose response plots were constructed for the plants extracts, from which the $\mathrm{LD}_{50}$ of the leaf aqueous extract was determined. The $\mathrm{LD}_{50}$ was calculated according to Lorke's method using the formulae. ${ }^{15}$

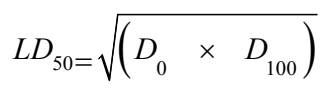

$\mathrm{D}_{0}$ : Highest dose that gave no mortality.

$\mathrm{D}_{100}$ : Lowest dose that produced mortality.

The animals were weighed before and after administering the crude extract in order of $200 \mathrm{mg} / \mathrm{kg}, 400 \mathrm{mg} / \mathrm{kg}, 600 \mathrm{mg} / \mathrm{kg}$, and $800 \mathrm{mg} / \mathrm{kg}$ body weight with regards to the $\mathrm{LD}_{50}$ of $4525 \mathrm{mg} / \mathrm{kg}$ body weight, using oral administration for 28 days. On day 29, all animals were sacrificed by cervical dislocation; the Kidney, Liver and Small intestine was excised and preserved in 10\% Neutral Buffered Formalin and transported to the Laboratory for tissue processing using the automatic tissue processor. Average weight of rats $=172.6 \mathrm{~g}$. Each rat in group $\mathrm{A}, \mathrm{B}, \mathrm{C}, \mathrm{D}$ and $\mathrm{E}(\mathrm{n}=5)$ were picked one at a time with a hand towel and a dose of $200,400,600$ and $800 \mathrm{mg} / \mathrm{kg}$ body weight (b.w) respectively were administered orally using a sterile $5 \mathrm{ml}$ syringe. 
Nonetheless, group A served as the control. Each animal was weighed before and after administering the test extract. The experiment lasted for 28days, oral treatment were given daily while on day 29; all animals were sacrificed by cranial-spinal dislocation. The kidney, liver and small intestine of the animals (treated and untreated groups) were excised and examined grossly. After that it was processed histologically by the automatic tissue processor (Hestion- ATP7000 Tissue processor- Germany). The selected organs such as the kidney liver and small intestine from each group of each animal were fixed in $10 \%$ Neutral Buffered Formalin for $48 \mathrm{hrs}$ following grossing at $3-5 \mathrm{~mm}$ in diameter. Subsequently, they were dehydrated in graded concentration of ethanol (ascending grades), cleared in xylene and embedded in paraffin wax for sectioning. After that, sections of about $3-5 \mathrm{~mm}$ in thickness were obtained using the Hertz rotary Microtome (Leica RM2255, Cambridge Mode) and mounted on glass slides. Staining of the section was according to Haematoxylin and Eosin (H \& E) technique and Periodic Acid Schiff (PAF) technique and was examined using Swift $^{\circledR}$ binocular microscope with an inbuilt lightening system (Olympus, England). ${ }^{14}$

\section{Protocols for heamtoxylin and eosin}

i. Deparaffinize tissue slides in xylene.

ii. Hydrate in decreasing grades of alcohol $(100 \%, 95 \%, 90 \%$, $70 \%$,).

iii. Stain in cole's hematoxylin 3-5mins

iv. Rinse in distilled water.

v. Differentiate in $1 \% \mathrm{HCL}$ in $70 \%$ alcohol, briefly ( $5 \mathrm{secs})$.

vi. Rinse in distilled water, Blue in scott's water for 5 mins.

vii. Counter stain with $1 \%$ eosin solution for 2 mins.

viii. Rinse in distilled water, Dehydrate in increasing grades of alcohol $(70 \%, 90 \%, 95 \%, 100 \%)$, rinse in water, Clear in
Xylene, Mount with synthetic medium. Observe under the microscope.

ix. Protocol for Period Acid Schiff technique.

$\mathrm{x}$. Deparaffinize tissue slides in xylene.

xi. Hydrate section in decreasing grades of alcohol (100\%, 95\%, $90 \%, 70 \%$,).

xii. Rinse in water, oxidize sections in $1 \%$ periodic acid for 5minutes.

xiii. Wash sections thoroughly in running tap water, Place in Schiff reagent for 15 minutes,

xiv. Wash in lukewarm Water for 5 minutes, counter stain nuclei with Erlich's Hematoxylin for 1 minute.

$\mathrm{xv}$. Wash sections in water for 5 minutes, dehydrate sections in increasing grades of alcohol $(70 \%, 90 \%, 95 \%$, and $100 \%)$, Clear sections in xylene, Mount in synthetic medium. ${ }^{14}$

xvi. Observed under the microscope)

\section{Photomicrography and statistical analysis}

Olympus photomicroscope (Opticshot-2; Nikon, Tokyo, Japan) was used at x40 magnification. Data were presented as Means \pm S.E.M and significance were determined at $p<0.05$ using one way analysis of variance (ANOVA) and differences between pairs of means within the five groups of rats (treated and untreated) were made by using the Student's Newman-Keuls test.

\section{Results}

Empirical and Physical Measurements of wistar rats treated with oral administration of Anacardium occidentale leaf extract for 28days (Table 1) and (Figures 1-6).

Table I Empirical and physical measurement

\begin{tabular}{llllll}
\hline Cages & $\begin{array}{l}\text { Dose In Mg/ } \\
\text { Kg B.W. }\end{array}$ & $\begin{array}{l}\text { Mean average weight before } \\
\text { administration of extract }\end{array}$ & $\begin{array}{l}\text { Mean average weight after } \\
\text { administration of extract }\end{array}$ & $\begin{array}{l}\text { Physical weight } \\
\text { loss or gain }\end{array}$ & Activities/dullness \\
\hline A & 000 & 181.95 & 194.41 & $\uparrow \uparrow$ & - \\
B & 200 & 147.38 & 145.23 & $\downarrow$ & \pm \\
C & 400 & 178.45 & 170.15 & $\downarrow$ & \pm \\
D & 600 & 173.73 & 164.63 & $\downarrow$ & + \\
E & 800 & 181.25 & 159.81 & $\downarrow$ & ++ \\
\hline
\end{tabular}

Average weight of rats $=172.6 \mathrm{~g} \pm 4.8($ Mean \pm S.E.M)

Key to histological scoring

$\uparrow \rightarrow$ Slight increase in weight.

$\uparrow \uparrow \rightarrow$ Marked increase in weight.

$\downarrow \rightarrow$ Slight weight loss

$\downarrow \downarrow \rightarrow$ Severe weight loss

$+\rightarrow$ Presence of features

$\pm \rightarrow$ Intermediate features

$++\rightarrow$ Marked presence of features

- $\rightarrow$ Absence of features. 


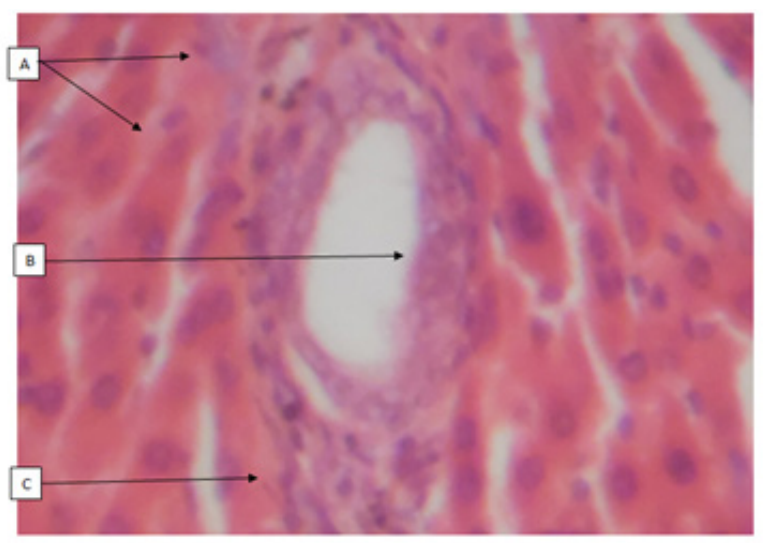

Figure I Photomicrograph of the rat liver section composed of A, hepatocytes, $B$, Bile duct and C, sinusoid (H\&E x I00).

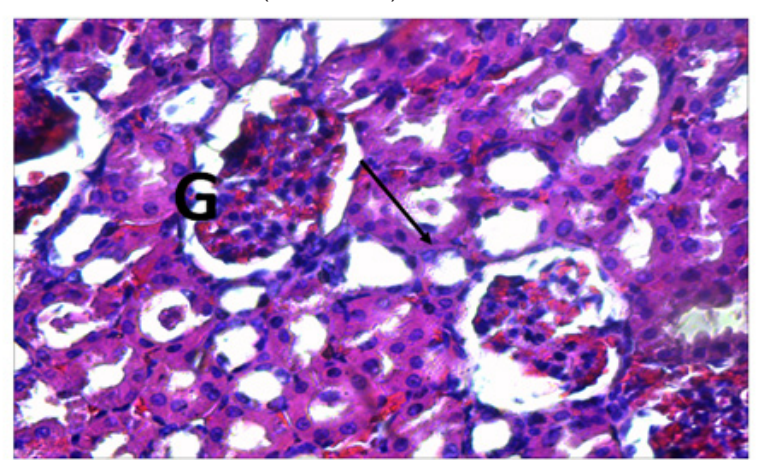

Figure 2 Section of rat kidney tissue. Note the normal glomerulus (G) and normal tubules $(\rightarrow)$ Stain: Heamatoxylin and Eosin Magnification: $x 400$.

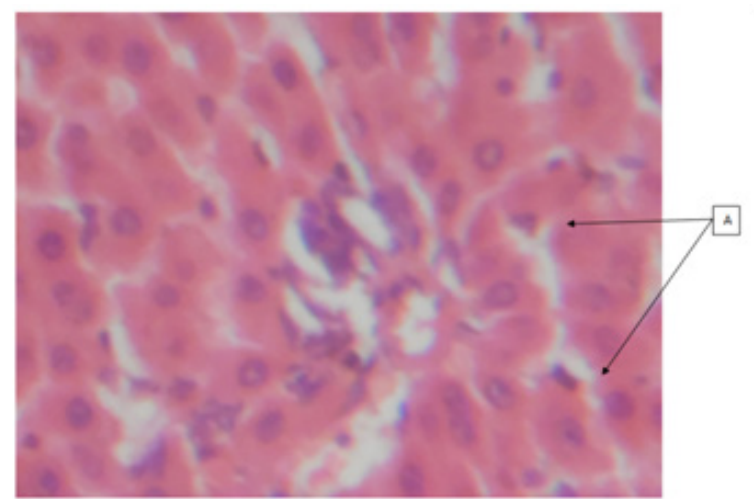

Figure 3 Photomicrograph of the rat liver section given $200 \mathrm{mg} / \mathrm{kg}$ A. occidentale leaf extract showing A, moderate kupffer cell activation (H\&E x I00).

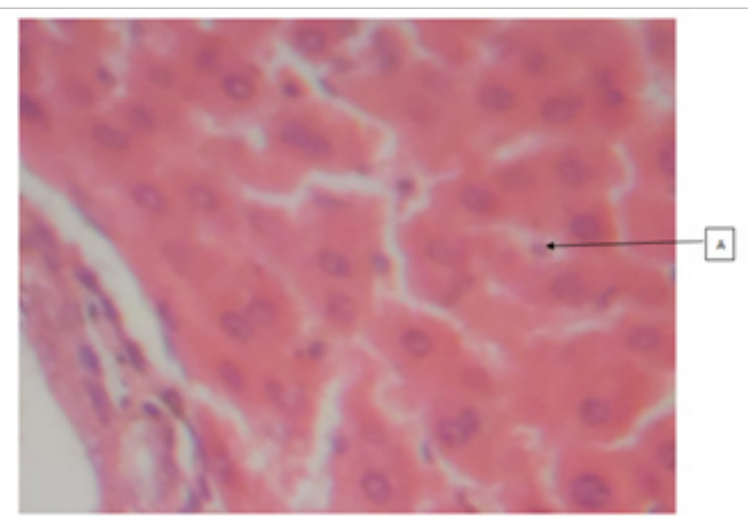

Figure 4 Photomicrograph of the rat liver section given $400 \mathrm{mg} / \mathrm{kg} \mathrm{A}$. occidentale leaf extract showing A, mild kupffer cell activation (H\&E x 100).

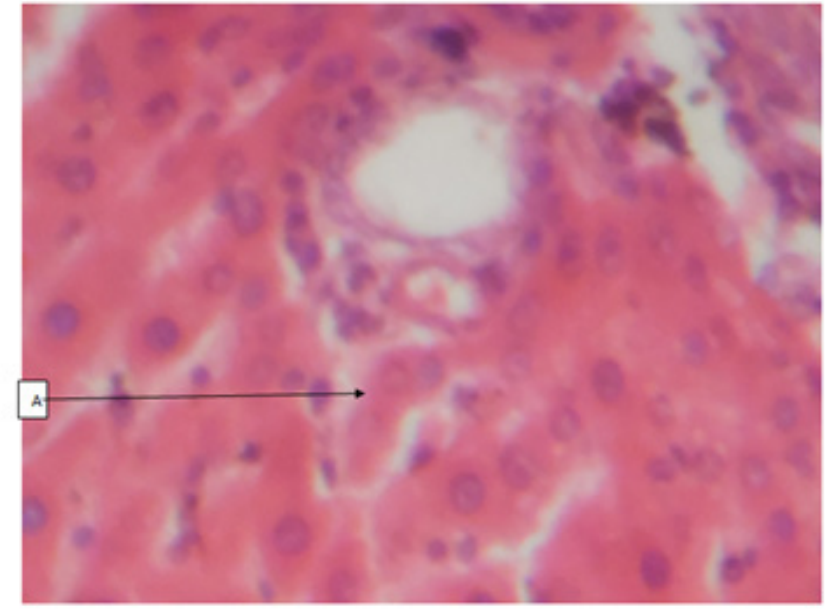

Figure 5 Photomicrograph of the rat liver section given $600 \mathrm{mg} / \mathrm{kg}$ A. occidentale leaf extract showing A, moderate kupffer cell activation (H\&E x 100).

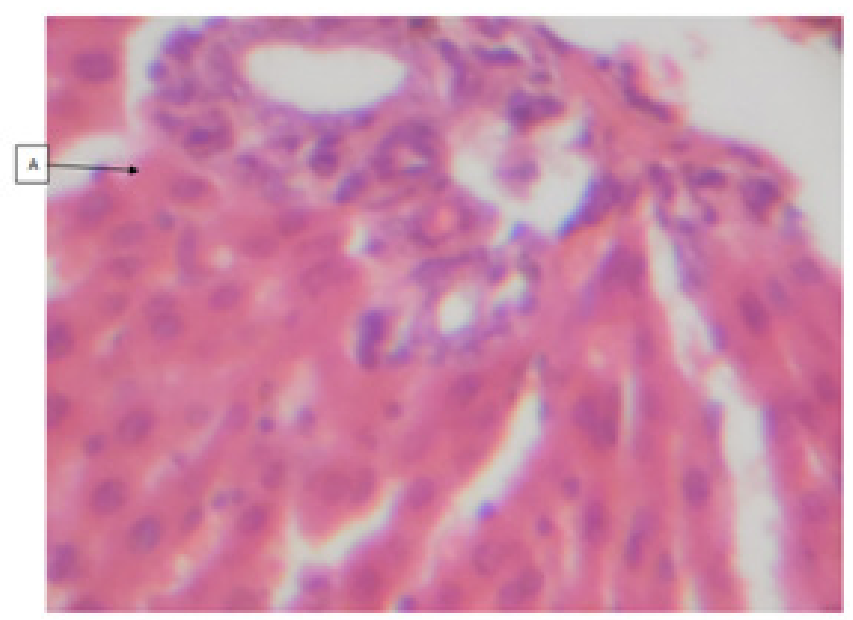

Figure 6 Photomicrograph of the rat liver section given $800 \mathrm{mg} / \mathrm{kg} A$. occidentale leaf extract showing A, mild kupffer cell activation (H\&E x 100).

\section{Discussion}

Cashew (A. occidentale) tree has been used medicinally worldwide. The bark, leaves and shell oil of the plant are used medicinally to treat different ailments. ${ }^{16}$ All parts of the plant (apple, bark, leaves, gum, nut and roots) have different ethno-medicinal uses for both man and animal alike. Medicinal plants are believed to be an important source of new chemical substances with potential therapeutic effects. ${ }^{17}$ However, investigation on the phytochemical constituents of the plant extract also revealed, the presence of bioactive ingredients in the cashew leaves like carbohydrates, tannins, saponins, resins, alkaloids and flavonoids add to their antimicrobial activities. The results of the $\mathrm{H} \& \mathrm{E}$ reactions revealed that with increasing dose of ethanolic extract of $A$. occidentale, there were varying degrees of activation of kupffer cells in the sinusoids of the liver. In $400 \mathrm{mg} / \mathrm{kg}$ body weight and $800 \mathrm{mg} / \mathrm{kg}$ body weight concentration, it can be seen that the activation of the kupffer cells were noted as mild while in $200 \mathrm{mg} / \mathrm{kg}$ body weight and $600 \mathrm{mg} / \mathrm{kg}$ body weight concentration, the activation of the kupffer cells were noted to be moderate. The difference in the immunologic response to the concentration administered could be due to the varying immune system of the rats before administration of the ethanolic extract. This could also mean that, in 200 and $600 \mathrm{mg} / \mathrm{kg}$ body weight, (Group B and E), the immune system of the rats before administration was weak compared to after administration of the dosage where the kuffer cells became active (moderate) in response 
to the ethanolic extract induced in rats. From previous research work carried out on the role of kupffer cells in the pathogenesis of liver disease, it was noted that, kupffer cells are the first cells to be exposed to materials absorbed from the gastrointestinal tract. ${ }^{16}$ The ability to eliminate and detoxify microorganisms, endotoxins, degenerated cells, immune complexes and toxic agents (example is ethanol) is an important physiologic function of the kupffer cells. This futher proves that besides the ethanol used in the extraction of $A$. occidentale leaf, the leaf (A. occidentale) itself is not a toxic agent. In other words, the extracts administered to (Groups B and E) 200 and $600 \mathrm{mg} / \mathrm{kg}$ body weight only served as a boost to the immune system of the rat, enabling elimination of the toxic agent (ethanol) introduced into the liver through blood circulation. However, the same could also be applied to group C and E (400 and $800 \mathrm{mg} / \mathrm{kg}$ body weight) having mild activations of the kupffer cells, in which the immune system of the rat before administration was already said to be active. And after administration of the concentrations, there was only a mild boost to the presence of the ethanol (toxic agent) in the extract. This is in agreement to the previous studies carried out in anti-microbial activities regarding the hepatic stage of the malaria parasite's life cycle. ${ }^{17}$ Furthermore, the results for the H\&E staining reaction for the kidney, revealed that, with increasing dose of ethanolic extract (200, 400,600 and $800 \mathrm{mg} / \mathrm{kg}$ body weight) of $A$. occidentale, there was no presence of any deleterious effects of the ethanolic extract on the glomeruli, tubules and interstitial spaces of the kidney. In a study, Van Thiel and colleagues (1997) compared kidney structure and function in ethanol-fed and control rats. The ethanol-fed group experienced kidney swelling and significantly reduced kidney function. Therefore, this further suggests that $A$. occidentale leaf is not toxic to the histology of the kidney despite the use of ethanol. This findings, is also in agreement to earlier research works done on urinary insufficiency which is a medical condition in which the kidneys fail to adequately filter waste products from the blood (medicine plus, 2012). The PAS stain (a special stain) was used as a confirmation of the result and also to determine whether the cytoplasm of the tubules involved in filtration, reabsorption and secretion processes, was affected in the course of administration, which also proves to be normal. For $200 \mathrm{mg} /$ $\mathrm{kg}$ and $400 \mathrm{mg} / \mathrm{kg}$ body weight, there was mild muscularis mucosa congestion, which also exhibited mild signs of inflammation as a result of the ethanolic concentration used. While, in the higher dose, $(600 \mathrm{mg} / \mathrm{kg}$ and $800 \mathrm{mg} / \mathrm{kg})$, there was more effect on the mucosa and mucosa architecture of the small intestine. The effect of the ethanolic extract of $A$. occidentale on the histology of the small intestine, led to normal and moderate congestion in the mucosa architecture and mucosa respectively. The present findings are in agreement with the previous research carried out in gastrointestinal tract disorder for diarrhea. Whereby, with the exemption of ethanol, the leaves of cashew which are a rich source of tannins, a group of plant chemicals with documented medicinal activity demonstrated in anti-inflammatory and astringent effects, are effective in treating diarrhea. ${ }^{18} \mathrm{Had}$ earlier reported that tannins isolated from the medicinal plant has therapeutic activity against bacteria and fungi and may assume pharmacological importance in the near future. Furthermore, the present findings is also in agreement with the research work carried for dyspepsia (a condition of impaired digestion), which ${ }^{19}$ reported that the leaf of cashew can be used in treatment of dyspepsia. The ability of the cashew leaf had also been attributed to the presence of flavonoids found in the leaf of cashew. ${ }^{20}$ Thus, the agreement can be clearly pointed out when comparing the evidence of the present findings (using ethanolic extract) with the previous research work (using an aqueous extract), on A. occidentale in gastrointestinal tract disorders (diarrhea and dyspepsia) of the small intestine, it can said that ingestion of high dose of ethanolic $A$. occidentale extract, is more likely to cause not only congestion, but alterations in the mucosa architecture and inflammatory effects on muscularis mucosa.

\section{Conclusion}

The results obtained in this study revealed that the ethanolic extract of $A$. occidentale at low and high doses $(200$, and $600 \mathrm{mg} / \mathrm{kg}$ body weight in wistar rats) adversely affect the liver. In addition, the hepatocyte (kupffer cells) of the liver of the wistar rats that received a low (200mg/kg body weight) and high dose (600 mg/kg body weight) of the ethanolic extract showed more activation of the kupffer cells to the toxic extract. Therefore, it is impossible that the functions of the liver as a major metabolic and immunologic organ may be adversely affected. However, the results obtained in this study also revealed that A. occidentale leaf extract at varying concentrations $(200,400,600$, and $800 \mathrm{mg} / \mathrm{kg}$ body weight) had no adverse effect on the kidney of the wistar rat but however, resulted to an enhanced histological feature of the kidney. Therefore, it is further impossible that the functions of the kidney as a major role in filtration, absorption, secretion and excretion may be adversely affect The results also obtained in this study of $A$. occidentale leaf extract at different concentrations (200, $400,600,800 \mathrm{mg} / \mathrm{kg}$ body weight) revealed, more adverse effects on the muscularis mucosa, mucosa architecture and mucosa of the small intestine of wistar rats. Therefore, it is impossible that the functions of the small intestine as a major role in the support of the mucosa and the absorption of digested nutrients may be adversely affected.

\section{Recommendation}

It is therefore recommended that, a different method extraction of A. occidentale leaf should be used to prevent the damage of these organs and their roles. The concentration of the dose administered should be less than the dose of administration used in this study. Finally, further investigations should also be carried out on this research work.

\section{Acknowledgements}

None.

\section{Conflict of interest}

The author declares no conflict of interest.

\section{References}

1. Farnsworth NR, Akerele O, Bingel AS, et al. Medicinal plants in therapy. Bull World Health Organiz. 1985;63(6):965-981.

2. Morton JF. Fruits of warm climates. UK: Flair Books; 1987.

3. Kubo K, Akima H, Kouzaki M, et al. Changes in the elastic properties of tendon structures following 20 days bed rest. Eur J Appl Physiol. 2000;83(6):463-468.

4. Toyomizu. Reducing effect of dietary anacardic acid on body fat pads in rats. Animal science journal. 2003;74(6):499-504.

5. Veiga Jr VF, Pinto AC, Maciel MAM. Plantas medicinais:cura segura? Quimica Nova. 2005;28:519-528.

6. Jaouad IC, Elalaoui SC, Sbiti A, et al. Consanguineous marriages in Morocco and the consequence for the incidence of autosomal recessive disorders. J Biosoc Sci. 2009;41(5):575-581.

7. Mota ML, Lobo LT, Costa JM, et al. In vitro and in vivo antimalarial activity of essential oils and chemical components from three medicinal plants found in northeastern Brazil. Planta Med. 2012;78(7):658-664. 
8. França LR, Avelar GF, Almeida FFL. Spermatogenesis and sperm transit through the epididymis in mammals with emphasis on pigs. Theriogenology. 2005;63(2):300-318.

9. Prema Latha K, Soni R, Khan M, et al. Exploration of Csp genes from temperate and glacier soils of the Indian Himalayas and in silico analysis of encoding proteins. Curr Microbiol. 2009;58(4):343348 .

10. Polasa K, Rukmini C. Mutagenicity tests of cashew nut shell liquid, rice bran oil and other vegetable oils using the Salmonella typhimurium/ microsome system. Food Chem Toxicol. 1987;25(10):763-766.

11. Venkatachalam M, Sathe SK. Chemical composition of selected edible nut seeds. J Agric Food Chem. 2006;54(13):4705-4714.

12. Laurens AC. Screening of some medicinal plants for antimicrobial activity. J. Ethnopharma. 1999;67(2):225-228.

13. Tedong L, Dzeufiet PDD, Dimo T, et al. Acute and subchronic toxicity of anacardium occidentale linn. (Anacardaiceae) leaves hexane extract in mice. Afr. Afr J Tradit Complement Altern Med. 2007;4(2):140-147.

14. Iyiola S, Avwioro OG. Alum haematoxylin stain for the demonstration of nuclear and extra nuclear substances. Journal of Pharmacy and Clinical Sciences. 2011.
15. Madara AA, Ajayi JA, Salawu OA, et al. Anti-malarial activity of ethanolic leaf extract of Piliostigma thonningii Schum. (Caesalpiniacea) in mice infected with Plasmodium berghei berghei. African Journal of Biotechnology. 2010;9(23):3475-3480.

16. Agedah CE, Bawo DDS, Nyananyo BL. Identification of antimicrobial properties of cashew, Anacardium occidentale L. (Family Anacardiaceae). Int J Appl Manage Sci. 2010;14(3):25-27.

17. OYESOMI, Tajuden Oyesina and AJAO Moyosore Salihu. Histological effect of aqueous extract of Anacardium occidentale (Cashew) stem bark on adult Wistar rat testis. Medical Practice and Review. 2011;2(7):73-77.

18. Banso A, Adeyemo SO. Evaluation of antibacterial properties of tannins isolated from Dichrostachys cinerea. African Journal of Biotechnology. 2007;16(15):1785-178.

19. Talley NJ, Lam SK, Goh KL, et al. Management guidelines for uninvestigated and functional dyspepsia in the Asia-Pacific region: first Asian pacific working party on functional dyspepsia. $J$ Gastroenterol Hepatol. 1998;13(4):335-353.

20. Jellin JM, Gregory P, Batz F, et al. Pharmacist's Letter/Prescriber's Letter Natural Medicines Comprehensive Database. 3rd ed. USA: Therapeutic Research Faculty; 2010. p. 249-250. 